\title{
Pluralism, Disagreement, and the Status of Argument in the Public Sphere
}

\section{Robert Asen}

\author{
University of Wisconsin - Madison
}

\begin{abstract}
Argument teachers and scholars have frequently invoked external justification-impressing one's viewpoint upon another-as the primary social function of argument. Pluralism and fundamental disagreement in contemporary democratic societies raise questions regarding the status of argument, including the functions argument should serve. In this essay, I suggest alternatives of agenda expansion, responsibility attribution, and identity formation as important functions of argument in diverse societies. These alternative functions are especially important under conditions of social inequality, since they allow less powerful individuals and groups to confront more powerful actors in situations where decision making is not open to all.
\end{abstract}

Résumé: Les enseignants et les savants de l'argumentation ont souvent invoqué la justification externe-la tentative de faire bien comprendre notre point de vue aux autres - comme la fonction sociale principale de l'argumentation. Le pluralisme et les désaccords dans des sociétés démocratiques contemporaines font soulever des questions sur le statut ainsi que sur la fonction des arguments. Dans cet essai je suggère différentes fonctions importantes des arguments dans diverses sociétés: l'expansion des buts qui sous-tendent l'argumentation, l'attribution des responsabilités, et la formation de l'identité. Ces fonctions alternatives sont particulièrement importantes dans les conditions sociales d'inégalité, car elles permettent à des individus et à des groupes impuissants de confronter les plus puissants dans des situations où la participation au processus décisionnel n'est pas ouvert à tous les gens.

Keywords: argument, pluralism, diversity, public sphere, justification

\section{Introduction}

Fundamental disagreement amid value pluralism characterizes public life in contemporary democratic societies. In the United States, public debates address a wide range of topics, including such issues as the proper legal definition of marriage, the appropriate conduct of military operations abroad, the duties of a patriotic citizen, and the future prospects of social insurance programs designed to ensure workers a basic retirement income. Underlying these debates are basic disagreements over the place of religion in public life, the role of the state in society, and the obligations that citizens have toward one another. Together, these specific and 
general issues produce what James Bohman has termed "deep conflicts" arising from the pluralism of contemporary societies (2003: 759-61). Unlike the pluralism of the Liberal tradition, which concerned religion primarily, contemporary pluralism engenders disagreements that implicate multiple and intersecting aspects and dimensions. Aspects address axes of cultural, social, and epistemic diversity; dimensions concern domains of values, perspectives, and opinions. Public debates over issues like same-sex marriage involve matters of cultural, social, and epistemic import, and these aspects lead advocates to draw on different-and potentially incommensurable - norms and perspectives in articulating their opinions. No shared framework exists for participants to decide the issue in a mutually agreeable fashion.

This is one of the lessons of Habermas's historical account of the bourgeois public sphere (Habermas 1989). As social movements democratized the public sphere, extending participation beyond the bounds of the bourgeoisie, existing interpretive and value frameworks for public debate became unmoored and debate less consensus-based. A fractious public sphere ensued. The shared understandings that guided debate in the bourgeois public sphere no longer provided a common background knowledge. Participants struggled to develop new frameworks and understandings. However, we should not read Habermas's historiography as appealing to logical necessity. We do not face an inevitable trade-off between exclusive cohesion and inclusive disorder in public life. Rather, the eclipse of the bourgeois public sphere represented a historical development. No intrinsic obstacle existed (or exists) to democratizing public spheres and widening public understandings.

Nevertheless, our contemporary situation and historical accounts raise the question of the status of argument in a diverse society characterized by value pluralism and fundamental disagreement. Both factors contribute to our present difficulties. If value pluralism existed without fundamental disagreement, we could enjoy the benefits of diversity without attending as much to its complications. If fundamental disagreement existed in a context of shared values, we could invoke authorizing norms and perspectives to settle disagreements. Status, too, raises cause for concern. For some, the status of argument refers simply to the question of whether genuine argument occurs under current conditions. In a recent $\mathrm{New}$ York Times op-ed essay, Matt Miller, a columnist for Fortune magazine, answers "no." According to Miller (2005: A 15), persuasion is "dead": "Marshaling a case to persuade those who start from a different position is a lost art." Instead, pundits direct their discourse to readers and listeners who already agree with them. When confronted by someone who holds a different view, advocates reduce their arguments to talking points. Miller contends that the "purpose of most political speech is not to persuade but to win, be it power, ratings, celebrity, or even cash." Miller correctly diagnoses present pathologies in contemporary political culture, and his attention to the purposes of persuasion (or argument) is well-directed. However, approaching the issue as a question of yes or no-whatever one's level 
of optimism or pessimism-oversimplifies matters. We ought to approach status not as a question of occurrence but rather as an inquiry into functions of argument.

Inquiring into the functions of argument may help us address its complexities in a diverse society. If, like Miller, we always expect argument to marshal "a case to persuade those who start from a different position," then we are bound to be disappointed. It is hard to imagine what someone who considers herself prochoice on abortion might say to persuade someone who is firmly pro-life to change his views. Yet, considering the functions of argument goes beyond predictions of likely success or failure. Under conditions of pluralism and disagreement, argument may serve other important functions that cultivate the benefits of diversity while ameliorating some of its difficulties. I call the purpose attributed to argument by Miller the justificatory function of argument. From this vantage point, the function of argument is to justify one's viewpoint to another. To be sure, this is an important function of argument-but it is not the only function. Without purporting to offer an exhaustive list of alternatives, I consider functions of agenda expansion, responsibility attribution, and identity formation. Agenda expansion entails widening the agendas of public spheres to include the interests and perspectives of marginalized individuals, groups, and issues. Responsibility attribution refers to situations in which less powerful actors compel more powerful actors to accept public responsibility for decisions that they have made in restricted deliberative situations. Identity formation refers to the use of argument by advocates as a means of shaping individual and collective identity. My purpose in considering these functions of argument is to suggest a wider context for its practice, one that comports with the varied significance of argument in our diverse contemporary society.

My essay develops in three sections. The first section discusses the prominence given to the justificatory function in historical and contemporary argument scholarship and pedagogy. My discussion requires a distinction between internal and external justification.' Internal justification may be a characteristic of all argument insofar as it identifies the inferential relationship between an argument's premises and conclusions. External justification refers to the function ascribed to argument in instances of social interaction, namely, to impress one's viewpoint upon another. It is this second sense of justification that needs to be supplemented by additional functions. The second section of this essay explains developments in public sphere scholarship that underscore the need for reconsidering argument's functions. Reconfigurations of the public sphere through metaphors of networks or constellations have highlighted the differential power relationships that inform discursive exchanges in multiple forums. From this perspective, alternative argument functions may bolster interactions in less-than-ideal situations. The third section of this essay explicates the functions of agenda expansion, responsibility attribution, and identity formation. In doing so, I hope to foster further discussions of the status of argument in the public sphere. 


\section{Argument and Justification}

Miller provides a popular - and, perhaps purposefully, provocative - assessment of the status of argument in contemporary political culture. In the process, he presents a reductive and bifurcated description of argument's current condition (i.e., either argument persuades people whose viewpoints differ or argument is dead). To be sure, pedagogy and scholarship exhibit a more nuanced approach to the status of argument. Important and illuminating books, articles, and textbooks have explored the relationship between argument and justification. One approach has considered justification as characteristic of the inferential quality of arguments. A second approach has implicitly and explicitly identified justification as the function or aim of argument as a social practice.

As characteristic of inference, internal justification describes the relationship between the premises and conclusions of an argument. The premises of an argument justify-or provide support for-its conclusions. On this basis arguments may be distinguished from other discursive acts. In his 1950 textbook, Monroe Beardsley defines argument as "a discourse that contains at least two statements, one of which is asserted to be a reason for the other." The two statements exhibit a justificatory relationship; one statement provides backing for the other. Beardsley's definition serves as the basis of his distinction between "discourse that merely states and discourse that gives reasons" (1950: 9). When discussing public affairs, students may simply opine, or students may indicate why they regard a particular position as right and proper. Clearly, Beardsley hopes to motivate his student readers to pursue the latter option.

This view of argument informed scholarship in the formative years of argument studies in North America, as teachers of public address broke away from departments of English in the early twentieth century to establish departments of Speech. Although not a public address scholar, John Dewey's scholarship influenced inquiries into speech and argumentation. ${ }^{2}$ His 1910 book, How We Think, outlines a five-step process for critical thinking that became a standard in speech textbooks in the following decades. How We Think may be credited with inaugurating inquiry into critical thinking, which today appears in classrooms as an important means of teaching argument. Dewey uses the term "reflective thinking," which he defines as "active, persistent, and careful consideration of any belief or supposed form of knowledge in the light of the grounds that support it, and the further conclusions to which it tends" (1910: 6; italics in original). In this definition, we can discern a justificatory relationship between a belief and its grounds of support. Reflective thinking involves the inquirer in a process through which previously unexamined beliefs obtain reasonable support. Reflective thinking entails a process of suggestion that marks observed, known signs as evidence for unobserved, unknown objects and ideas. Signification establishes a "warrant" between known and unknown things. 
Although Dewey did not use the terms "premise" and "conclusion," his view of reflective thinking invoked the inferential relationship appealed to by argument scholars in succeeding years. In the 1920s, Herbert Wichelns drew on this relationship in a scholarly debate over argument pedagogy. Defending the classroom assignment of argument briefs against the charge that such briefs were overly syllogistic, Wichelns asks: "What is the common brief but a device for separating what we think from why we think it?" (1925: 268). Argument pedagogy could survive without the syllogism but not without the brief. In distinguishing "what we think" from "why we think it," Wichelns draws a distinction between one's position and the reasons that justify one's position. In her contemporary textbook, $A$ Practical Study of Argument, Trudy Govier provides a definition of argument as well as a distinction between argument and non-argument that recall earlier approaches. Govier writes that an argument is "a set of claims that a person puts forward to show that some further claim is rationally acceptable" (1996:2). As this definition suggests, Govier highlights justification as characteristic of argument. In some cases, determining whether one has encountered an argument may be tricky, since some forms of discourse use indicator words that suggest the presence of an argument but actually serve some other purpose. Explanation is one such case. However, for Govier, the difference is clear: "Arguments offer justifications; explanations offer understandings" (ibid.: 18). Both arguments and explanations place statements in inferential relationships, so neither can be distinguished on this basis alone. It is the quality of the inference that is significant.

My examples illustrate that scholars have long regarded internal justification as a crucial element of argument. Whether it is a necessary element I cannot say. It appears to be the case that theories articulating a premise-conclusion model of argument-or, in Wichelns terms, drawing a distinction between "what we think" and "why we think it" - typically rely upon inferential justification or some similar concept. But not all theories articulate a premise-conclusion model of argument. Recent work in visual argument leaves open the question of how visual images may be analyzed as arguments. ${ }^{3}$ This question notwithstanding, the prominence of appeals to internal justification has been paced in argument scholarship and pedagogy by appeals to external justification. Whereas internal justification enables evaluation of the cogency of the relationship between the premises and conclusions of an argument, external justification presents a function for argument that may be too narrowly construed.

Writing around the same time as Beardsley, A. Craig Baird appeals to justification as a function of argument in extolling its value to his student readers. "At the bottom yours is a government by talk," he maintains (1950:4). Debate stands as a bulwark against dictatorship; it sustains democratic participation. Both legislators and citizens alike need to engage in argument when conducting and keeping abreast of public affairs. Defining argument, Baird initially appeals to internal justification. He explains that "argumentation, whether written or spoken, is made up primarily 
of reasoning together with facts for your belief." Yet, he continues, "it is designed to convince and to persuade others to subscribe to your facts and principles and to the conclusions warranted by these premises and evidence" (ibid:: 7). In shifting from "reasoning together with facts" to "persuad[ing] others to subscribe to your facts," Baird shifts from defining an internal relationship of premises and conclusions to prescribing a function for argument in social relationships. Reasoning shifts from describing the dynamics of inference to identifying the motive for engaging in argumentation.

In his seminal study, which has since served as the foundation for most argument pedagogy and much argument scholarship in communication, Stephen Toulmin identifies justification as the "primary function of arguments." Toulmin maintains that "the other uses, the other functions which arguments have for us, are in a sense secondary, and parasitic upon this primary justificatory use" (1958: 12) There is some ambiguity in this statement regarding the location of argument justification. On one reading, justification may refer to the warrant linking the data and claim of an argument. Toulmin's warrant names a process of inference, and it resonates strongly with the other examples of internal justification cited above. However, in the paragraphs preceding this one, Toulmin holds that the justificatory function of argument arises from a social relationship. Justification fulfills an obligation set forth in making an assertion. Noting that an assertion puts forward a claim to another's interest and belief, Toulmin explains that an interlocutor can "challenge the assertion, and demand to have [one's] attention drawn to the grounds ... on which the merits of the assertion are to depend. We can, that is, demand an argument"(ibid.: 11). Justification here refers not to the relationship of an assertion and its grounds, but to the demand from another that one make this relationship explicit. Justification serves an external function: it demonstrates the soundness of one's view for another.

Appeals to external justification persist in contemporary argument scholarship. In their introduction to Fundamentals of Argumentation Theory, an important book that brings together lines of inquiry pursued in Europe and North America, the authors provide a definition of argumentation that, in their view, encapsulates its general characteristics and, in the process, sets justification as argument's aim. They write that "argumentation is a verbal and social activity of reason aimed at increasing (or decreasing) the acceptability of a controversial standpoint for the listener or reader, by putting forward a constellation of propositions intended to justify (or refute) the standpoint before a rational judge." (van Eemeren, et al.: 5; italics in original). The authors indicate that their definition applies both to the propositional and social aspects of argument. As social actors, arguers intend to justify their views to others. As with Toulmin's references to justification, this definition goes beyond describing an inferential relationship to prescribing a social function. The motive for argument is justification. Argument practices may be assessed by the degrees of adherence achieved by competing advocates. 
Appeals to the justificatory function of argument also appear conspicuously in the theoretical literature on deliberative democracy. In his influential eariy essay, Joshua Cohen delineates an ideal deliberative procedure that offers some guidance for determining if democratic decision-making may be deemed legitimate. In this ideal procedure, "deliberation is reasoned in that the parties to it are required to state their reasons for advancing proposals, supporting them, or criticizing them. They give reasons with the expectation that those reasons (and not, for example, their power) will settle the fate of their proposal" (1997: 74). For Cohen and some other deliberative democrats, the justificatory function of argument serves a foundational role in democratic societies. In addition to legitimating various laws and public policies, argument provides the basis for legitimating political institutions and arrangements themselves. Only deliberation can provide this basic justification, and it must produce outcomes that could be capable of assent by all citizens.

The problem with regarding external justification as the exclusive or primary function of argument is that it invokes an overly narrow context for the practice of argument and discounts other important functions that arguments may serve. Contexts of justification ascribe particular competencies, expectations, roles, and aims to advocates and audiences. From this perspective, people typically undertake argument in a situation in which a problem has arisen and a decision needs to be reached. A local school board, for example, meets to decide whether to initiate a bond referendum to raise revenues or to reduce the availability of music and sports programs for district students. Argument thus appears as a method by which the school board members may decide on one of these two options. In this case, the problem that has arisen and the decision to be made may be known before argument is engaged. In other cases, a problem may arise unexpectedly, without giving interlocutors an opportunity to prepare for argument. Such is the case, for example, when someone asserts during a social conversation that Bush's religious fundamentalism is a welcome change from the "secular" culture of the Clinton White House, only to be met with the response that Bush's faith improperly guides his public decisions. In some situations, the first comment may go unremarked, or it may meet with nods of approval. However, if someone raises an objection, each participant can expect the other to provide reasons to support his or her view of the proper role of religion in public office. In both examples, the role of argument appears to be the restoration of an equilibrium that has been disrupted by the emergence of a problem. Restoration occurs by reaching a decision, which may be unanimous, majority-driven, or stipulated for the sake of a specific interaction. Justification, then, tends to associate argument with situations of problem-solving, decision-making, and conflict resolution.

\section{Multiplicity, Diversity, and Value Pluralism}

The limits of justification may be seen by considering recent scholarship on the public sphere. One of the key theoretical moves in public sphere scholarship has 
been to emphasize the multiplicity of the public sphere. ${ }^{4}$ From this perspective, scholars have conceived of the public sphere through metaphors of networks or constellations. The public sphere, then, actually refers to numerous sites of discourse. Some of these sites are directly connected to each other, while others are connected only in the sense that they appear as part of an always changing network. The sites themselves are sites of discourse: specific locales may host forums, but these forums may not be reduced to their locales per se. So, for example, a town square or a grocery checkout line are not always sites in the public sphere. They emerge as such when people meet or gather in the town square or checkout line to discuss issues of common concern. The sites of the public sphere are multiple, intersecting, partially overlapping, shifting, and positioned relationally to other discursive sites. This suggests, too, that lines between public and private are not fixed and stable but negotiated through discursive engagement. To be sure, collectively held notions of public and private inform discursive encounters. However, the public or private status of an issue also depends upon where in a network someone stands. For example, feminists have worked hard to raise awareness of sexual harassment in the workplace as a public issue when others dismissed such concerns as private employment matters. Lines between public and private are always capable of being redrawn, and oftentimes the struggle of social reformers concerns precisely this effort at line drawing. ${ }^{5}$

Just as discursive sites are multiple and varied, so, too, do people act in the public sphere in numerous settings and in various ways. People do not confine themselves to a single site, nor do they always engage others in the same manner. In debates over the propriety of same-sex marriage, for example, someone may participate in a discussion with family members, co-workers, or protestors outside of a Massachusetts court house. Interactions in these different sites may vary. In a discussion with employees, a supervisor might be concerned to express the view that homosexuals would not be discriminated against in the workplace. In a discussion with one's teenage children, this same person may be less interested in allaying the concerns of subordinates and more interested in learning about generational differences in the social acceptance of same-sex couples. Roles may change as issues change. Someone who is regarded by others as a leader on one issue may be viewed as a foot soldier on another issue. Obligations and functions also change. Some instances of public engagement call on us to act as caring neighbors whereas others (in, say, the ever-increasing realm of reality television) call on people to behave as media personalities. Moreover, associations and alliances may shift across issues. Someone who is regarded by others as an ally on one issue may be seen as an adversary on another issue. A multiple public sphere thus recognizes the complexity that characterizes people's daily lives.

The move to multiplicity has been spurred by the perception that traditional accounts of the public sphere place too great an emphasis on a singular, overarching site of discourse. This often presumes that localized discussions may be subsumed 
within larger venues. ${ }^{6}$ Much of this reaction has been directed against Habermas's historical-critical account of the bourgeois public sphere. To be fair, Habermas may not be guilty as charged. After all, he explicitly notes the existence of a proletarian public sphere at the outset of Structural Transformation. I, for one, think that Habermas is far more ambivalent about the historical progress represented in the rise of the bourgeoisie than his critics oftentimes allow. Indeed, Habermas is quite explicit in stating that "the fully developed bourgeois public sphere was based on the fictitious identity of the two roles assumed by the privatized individuals who came together to form a public: the role of property owners and the role of human beings pure and simple" (1989:56; italics in original). Habermas notes that this did not trouble the bourgeoisie because they believed (wrongly) that others had the opportunity to obtain a propertied and educated standing and that, even if this did not come about, their deliberations were of a sufficiently general character to represent all interests. Given the mixed legacy of the bourgeois public sphere, Habermas concludes that its participants were perpetuating ideology and yet what they achieved was more than mere ideology. This measured judgment notwithstanding, Habermas has been taken in the work of Nancy Fraser and others to be an apologist or advocate of singularity (Fraser 1992: 109-42). ${ }^{7}$ Within the communication discipline, this reading of Habermas has become a kind of conventional wisdom.

Against the perceived traditional emphasis on singularity, the move to multiplicity has sought to recover alternative histories of public engagement. Scholars have studied how persons excluded from bourgeois forums have engaged others publicly in spite of explicit prohibitions and implicit social norms. ${ }^{8}$ Recovering alternative histories need not impugn the conceptual framework of the bourgeois public sphere. From this perspective, one could tell a story of expansion as successive groups have gained entry into public forums. This story would trace the problems of the bourgeois public sphere not to its structuring principles and underlying values but to its restrictive application. However, many scholars have made a stronger claim that the exclusions of the historical bourgeois public sphere were constitutive of the concept itself. From this perspective, the autonomy of the bourgeoisie necessarily depended on the exclusion and subjugation of women and laborers. ${ }^{9}$ Against its claims of universal representation, the bourgeois public sphere simply could not have emerged as a universal public sphere. Moreover, the norms governing discursive practices in this sphere necessarily reflected the (partial) interests and practices of the bourgeoisie.

While some have regarded this critique as a basis for rejecting the idea of a public sphere, most scholars have responded with calls to rethink contemporary notions of critical publicity. ${ }^{10}$ At least two important lessons can be drawn from this scholarship. First, all discursive forums reflect the histories of their participants. This means that no discursive forum proceeds as a tabula rasa but comes heavily coded with participatory norms. Sometimes these norms are enforced by authority, 
such as grounds for expulsion from an institutional hearing, while other times these norms are enforced by social sanction. Susceptible to change, norms provide a structuring influence on interactions. As reflective of specific histories, these norms advantage some participants and disadvantage others. Calls for "dispassionate" debate, for example, may actually reflect culturally specific ways of interacting. Such norms may effectively negate the distinct perspectives and contributions of "newer" participants. Second, participants speak from different positions in social hierarchies and networks, and these different positions have a bearing on the reception of one's discourse. "It may have been possible for the bourgeoisie to bracket status differences and debate each other as if they were equals, if only because the differences in status among participants in the bourgeois public sphere were comparatively small. In a more diverse setting, such as our contemporary society, such status bracketing is impossible. Put differently, the force of the better argument does not wholly decide how people deliberate about public matters. This is not simply the partial attainment of a praiseworthy standard. If we fail to take into account how difference informs public deliberation, then we fail to appreciate the full dynamics of actual discourse practices. Moreover, the implications need not be sinister, as my discussion so far has insinuated. Differences in standing explicitly acknowledged may add cultural diversity and vibrancy to public discourse.

A narrow justificatory context leaves us only partially equipped to consider the full implications of value pluralism and social hierarchies (and attendant relations of power) for the practice of argument. These aspects of contemporary diverse societies raise important issues for argument, including questions of where argument should begin, standards for judging the cogency of arguments, and grounds for determining when one should act on the basis of arguments. In terms of beginnings, for example, arguments about abortion often draw on incommensurable premises about when life begins, which may be based in various religious and secular traditions. So, arguments about abortion cannot presume a shared set of premises about society's obligation to protect life, nor can they presume a uniform measure for weighing the needs of an adult female against a fetus. The beginnings of arguments themselves need to be negotiated through debate, but the functions of this debate may be something other than justification. Questions regarding evaluative standards are perhaps more sharply drawn. One person may draw upon the precepts of Catholicism. Another person may turn to the teachings of Judaism. Both may present cogent arguments-arguments with reasonably acceptable premises, and relevant and sufficient relations between premises and conclusion-yet they may be unable to agree on an appropriate federal abortion law. Attempts to restrict such exchanges to a shared public reason, as scholars have shown, may be unsuccessful because recourse to public reason presumes a commonality whose very absence is the source of intractability on some contentious public issues. ${ }^{12}$ If a neutral option is unavailable, on what basis should we decide which standards should inform the federal law? A notion of plural public reason helps, but it seems to work best in situations where participants realize that they desire the same goal. ${ }^{13}$ For 
example, Christian conservatives and feminists may find common cause in a campaign to sponsor a municipal anti-pornography ordinance, but their plural reasoning depends on the shared goal of eliminating the public distribution of pornography. Questions of when to act may seem especially pressing in decisionmaking contexts. Sometimes, decisions have to be made in the face of value pluralism. Politicians have to decide whether or not to send troops into battle. Local communities have to decide whether or not to permit the opening of a national discount retailer in their town. In these kinds of cases, how much argument is enough? Is the goal a unanimous decision? Is a simple majority acceptable? How might a decision be made palpable to those who disagree with the outcome?

So far, I have considered the limits of a narrow justificatory context in a diverse but relatively egalitarian setting. By omission as much as anything else, my discussion has presumed that interlocutors encounter each other on roughly equal ground. Yet differences in values and perspectives also arise from differences in social standing, which entail differential access to cultural, economic, and political resources. Take, for example, debates about land-use policy. Imagine that a municipality is deciding what to do with an abandoned industrial plant near its downtown. Some community members wish to expand the city's green space, and argue that the former industrial plant should be demolished and replaced with a city park. Others wish to retain the industrial use of the plant and urge city leaders to seek a new occupant for the building. These differences may represent differences in socioeconomic standing. More affluent residents may be less concerned about retaining an industrial sector and more concerned with "quality of life" issues. Poorer residents may be more concerned with retaining sources of well-paying blue-collar jobs. Moreover, part of the dynamic informing this debate may entail not just a convergence of social position and opinion, but the possibility that those situated higher up the socioeconomic ladder may be better positioned to advance their interests. If differences in social positioning are especially great, and if well-connected participants are not open-minded in their approach to this issue, certain topics may be excluded from consideration altogether. The ensuing debate might not be about what to do with the abandoned plant, but how to design the green space that will take its place. Certain economic interests may be ruled out from the start. Or, certain presentation styles may be unduly influential. A city zoning board, for example, may privilege styles of speech that reflect upper-middleclass norms. Or, certain ideas may receive wider circulation apart from their intrinsic appeal. Promoters of a city park may be able to mount a media campaign that is beyond the resources of their opponents. Even in a more open debate, understanding the class implications of various options may be important, and this understanding may require participants to go beyond justification.

So, how may additional functions of argument address some of these issues? After all, focusing on agenda expansion, responsibility attribution, identity formation, or any other function will not necessarily bring about greater economic equality or 
adjudicate fundamental differences in religious belief. And yet, we cannot give up on deliberation in these and other situations. As scholars and teachers of argument, we need to continue to insist that discourse works. Indeed, the rhetorical tradition demonstrates clearly that people who lack economic and political resources can nevertheless engage in advocacy to enact social change. Recognizing different functions of argument allows us to recognize how discourse can address the larger contexts within which arguments occur. Participants can engage in deliberation not only to speak for or against an idea or policy, but to reshape the social context within which deliberation normally occurs. Sometimes, this reshaping may take hold right away. This happened, for instance, in the U.S. Senate in 1993, when Senator Carol Moseley-Braun, an African American from Illinois, eloquently reminded her colleagues of the racial implications of their (subsequently reversed) decision to renew a congressional patent for the emblem of the United Daughters of the Confederacy. ${ }^{14} \mathrm{~A}$ somewhat perfunctory debate about genteel tradition transformed into a touching debate, led most passionately by white Southern Senators, of the need to acknowledge the wrongs of history to create a more equal contemporary society. At other times, this reshaping may occur gradually over time. For instance, whatever may be the significance of Reagan's particular policy accomplishments, perhaps the most enduring legacy of his presidency is that he ultimately altered the framework of policy debates by challenging the capacities of government. In his inaugural address, Reagan encapsulated his theory of governance when he declared that "government is not the solution to our problem; government is the problem" (1982: 1).

\section{Functions of Argument}

In this section, I consider additional argument functions of agenda expansion, responsibility attribution, and identity formation. I do not offer comprehensive explications of each function; my purpose is to identify these additional functions and suggest some possibilities for further inquiry. Nor do I think that these three functions combine with justification to constitute an exhaustive list of argument functions. I discuss these functions because they may offer new perspectives for thinking about argument and the issues raised above.

Agenda Expansion. This function identifies the process through which individuals and groups seek to expand the agendas of wider public spheres. This is a dispersed, relational process; advocates approach wider publics from varying sites in the discursive network of the public sphere. There is no single, central public wide enough to encompass the public agenda. What counts as a wider public depends upon an advocate's position in a discursive network and interest in increasing the circulation of one's issues. Working-class feminists, for example, may wish to call greater attention to issues of class within feminist publics. In this case, a wider public would be comprised of a larger feminist community, which itself may seek to expand agendas of other publics in other situations. A relational 
view of agenda expansion suggests that issues are not simply "on" or "off" the public agenda. Issues are always on some public agendas and off others. Agenda expansion seeks an interaction and shift among public agendas. However, we should not view the relational quality of this function as indicating a delegation of responsibilities. ${ }^{15}$ There is no denying that some publics, such as legislative and quasi-legislative bodies, possess an institutional sanction for decision making that other publics lack. However, an a priori conceptual delegation of responsibilities discounts the dynamic multi-directional processes of agenda expansion that occur in various public spheres. Advocates may seek to establish relationships among any number of publics, and these relationships need not conform to institutional rules and procedures.

A high-profile example of agenda expansion took place in December 2004, in the context of the ongoing U.S. war with Iraq. Secretary of Defense Donald Rumsfeld visited the region to assess the progress of military operations. During his visit, Rumsfeld held a town-hall meeting with U.S troops in Kuwait. One may suppose that the meeting was scheduled to garner favorable press coverage for the Bush Administration's policies. However, the creation of a photo-op was disrupted when Specialist Thomas Wilson asked a question that challenged the preparation and administration of military planners since the outset of the war. Wilson queried Rumsfeld: "We've had troops in Iraq for coming up on three years and we've always staged here out of Kuwait. Now why do we soldiers have to dig through local landfills for pieces of scrap metal and compromised ballistic glass to up-armor our vehicles and why don't we have those resources readily available to us?" Sustained applause from fellow soldiers followed Wilson's question. Rumsfeld hesitated, asking Wilson to repeat the question. The Secretary then offered a rambling response. He insisted that the issue facing planners was a matter of productive capacity: "As you know, you go to war with the Army you have."16 Rumsfeld's attempt to dismiss the soldiers' concerns did not succeed. In the days and weeks that followed, editorialists and columnists mostly sided with Wilson. ${ }^{17}$

In asking his question, Wilson made an argument. To most observers, the context in which Wilson asked the question would have appeared unlikely to prompt the Secretary to reconsider his approach to the war. We do not need to know Wilson's intentions to say that his argument functioned to expand media agendas about the ongoing Iraq war. What was supposed to be a confirmation turned into a frank challenge to the conduct of the war by military officials and politicians. In effect, Wilson drew attention to the botched planning that subjected soldiers to unnecessary risk. Drawing attention-rather than justifying one's positioncharacterizes the aim of agenda expansion. Of course, there are non-argumentative ways of drawing attention to a position or a cause. Considering agenda expansion as a function of argument means that simply announcing a position is insufficient; publics must appreciate the significance of an advocate's position. That is, others must know not only the position one holds, but the reasons one holds a position. 
The "what" and "why" of argument discerned by Wichelns in the 1920s remains important for contemporary advocates engaged in agenda expansion. One could infer support for Wilson's implicit claim that the war had been mismanaged by referring back to his observation, which served as a premise, that planners had three years to make up for oversights apparent after the commencement of the war.

Responsibility Attribution. By this I mean the argumentative equivalent of putting people on record, having people accept their positions publicly so that they may take responsibility for their views. Forcing people to accept responsibility may be an important function of argument in cases where people of different social standing interact, especially in cases where these differences are great. For example, when particularly well-connected community residents interact with particularly disconnected others to determine the location for a new city energy plant, it may not be the case that all debate participants have an equal say in the outcome of their deliberations. Certainly, a perfunctory community hearing held by a public or private agency compelled to solicit citizens' viewpoints but not really interested in doing so suggests this very outcome. In these situations, it may be unrealistic to expect that arguments-even the most cogent arguments-going against the prevailing view can alter the outcome of a debate. Yet, I think it would be a mistake to say that argument is inappropriate in these contexts, or that argument is vitiated by distorted conditions of communication. To render either judgment would be to remove any potentially efficacious mode of participation for less powerful actors, short of reconfiguring the larger social conditions that lead to unequal communicative exchanges. Of course, this sort of ameliorative social action is important, but people also should participate in the exchanges available to them and not wait until larger social change has been achieved.

The importance of putting people on record became clear to me when I was conducting research for my book, Visions of Poverty. As part of my research, I conducted phone interviews with representatives of progressive research and advocacy organizations who had testified before congressional committees on the subject of welfare reform. Some of these witnesses testified in 1996 to oppose the law that effectively repealed Title IV of the 1935 Social Security Act, the Aid to Families with Dependent Children (AFDC) program. Its replacement, Temporary Assistance for Needy Families, offers a far weaker system of support for poor families. By the time the respective authorizing committees held their public hearings, there was no doubt that the legislation would be passed and AFDC would be repealed. Rep. Clay Shaw, chair of the House committee drafting the legislation, held a late-night hearing for numerous progressive groups so that he would not be open to the charge that people were excluded from the process. The hearing amounted to the DC equivalent of a Hollywood cattle call, in which participants were hastily considered so that the line of aspirants could be dispatched quickly. Given this situation, I asked the representatives why they bothered to testify at all. 
Their responses evoked a similar theme. They testified because they wanted to put members of Congress on record. The witnesses wanted to warn the members that they were headed down the wrong path. They wanted to make their objections public so that, when things went badly in the future, no one could say there was no warning. The representatives of the progressive groups I spoke with were not under the illusion that their testimony would change the minds of the commitee members, yet they knew that their testimony still served an important function.

Recognizing responsibility as an appropriate function of argument thus calls attention to two issues that might be overlooked in an exclusive justificatory focus. First, responsibility admits of situations in which the comparative social standing of people participating in argumentative exchanges influences the outcome of their deliberations. Responsibility suggests a way that these situations can be recuperated as meaningful even for participants who lack access to valuable political and economic resources. Second, responsibility concedes that sometimes argument occurs in situations where a decision already has been reached. To be sure, in a more perfect world, members of Congress would wait to hear from all witnesses before reaching a decision about whether to support a specific piece of legislation. Responsibility forces at least some scrutiny by not permitting decisions to go unnoticed. The very records created by advocates in these situations may contribute to wider social change.

Identity Formation. Interest in identity formation is an important contemporary development in rhetoric and related disciplines. Interest in identity has arisen as part of the larger "discursive turn" in the humanities, which has highlighted the constitutive power of language and symbols. From this perspective scholars have explored how discursive practice creates for participants a sense of self and others. Within rhetoric, identity has been approached from a range of perspectives, including feminist, social movement, and vernacular scholarship. ${ }^{18} \mathrm{~A}$ cross-disciplinary interest in identity also has been pursued through research on counterpublics, sites in the public sphere through which participants seek to develop alternative interpretations of relevant interests, needs, and identities and circulate these perspectives among wider publics. ${ }^{19}$ Identity also has raised conceptual problems for scholarship, most notably difficulties in distinguishing conceptually between individual and group identity. Iris Young has been a vocal critic of theories of group identity, holding that these theories tend to establish rigid inside-outside distinctions among groups that fix fluid social relations and deny differentiation within and across groups (Young 1997: 389-93). Her trenchant critique calls attention to the need for theorists of group identity to reflect on the relationship between individual and group identity in non-reductionist terms. Keeping in mind this difficulty, scholars of argument, too, ought to consider more explicitly the identity functions of argument.

An engaging example of identity formation occurred during a 1996 town hall meeting in South Central Los Angeles convened to discuss media allegations that the CIA had permitted drugs to be smuggled into California in the 1980 s as part of 
an alliance with insurgents seeking to overthrow the communist government of Nicaragua. The meeting featured CIA Director John Deutch. Deutch delivered a brief speech and participated in a question-and-answer session with community residents, both of which were televised by a national network. During the meeting, one young man, who did not identify himself, noted the presence of television cameras throughout the room. He commented that the national news media always turned its attention to places like South Central during times of crisis. The young man called for the cameras to remain after the crisis had subsided: "We need a camera right in the heart of South Central." He urged the media and viewers across the country to see South Central residents as they wished to be seen, not as residents were portrayed in media stereotypes. He exhorted that "we have a lot of talent here. We have a lot of hard-working people in this community who have worked with these kids on drugs that you guys never talk to. It's time for you to bring your cameras back to our community and let everybody in the other parts of the world know that we are not all on drugs, we are not all gangbangers, we are not all murderers." ${ }^{20}$ The young man cited the local involvement of community members as evidence for his claim that talented and hard-working people resided in South Central.

I am not suggesting that the hard work of community members would have little consequence if the young man had not spoken during the meeting. Nor I am suggesting that community members' hard work itself did not contribute to the formation of their identity. However, we should not insist on a strict separation of speech and action. The identity of South Central residents has been formed through innumerable social and discursive interactions. In the public sphere engendered by the meeting, the young man's argument for more favorable media representation, along with other participants' contributions, helped form community members' identities during the meeting and as its coverage circulated subsequently in other public spheres. To recognize the identity formation function of argument is to recognize that discourse situates people in social relations. Argument takes on a performative dimension as the articulation of a viewpoint bolsters the identity conveyed in one's propositional statement. ${ }^{21}$ The very act of praising the talent and hard work of South Central residents-apart from the specifics of this praisecountered negative media stereotypes with positive representations. The identity function of argument demonstrates that discourse does not exhaust itself at the level of enunciation.

\section{Conclusion}

Value pluralism and fundamental disagreement raise questions about the status of argument in contemporary democratic societies. To move beyond simple questions of argument's occurrence and to appreciate the multiple purposes that argument may serve, we need to think beyond external justification as the primary function of argument. In this essay, I have suggested three additional functions: 
agenda expansion, responsibility attribution, and identity formation. These three functions illustrate the importance of argument in a multiple public sphere conceived as a network. All three functions demonstrate how participants in various public spheres may engage diverse viewpoints, acknowledge their own positions, and create a sense of self.

In explicating these functions, my examples all invoke interactions characterized by unequal relations of power: the Secretary of Defense and a reservist; the chair of a congressional committee and representatives of non-profit organizations; the director of the CIA and a South Central Los Angeles resident. In each case, I examined arguments advocated by the less powerful participant in these interactions. These examples demonstrate the lessons of public sphere scholarship noted above: all discursive forums reflect the histories of their participants; a person's social standing has a bearing on the reception of one's discourse. The town hall meeting in Los Angeles was shaped partially by the histories of community members and their previous interactions with government officials. Further, regardless of what he said, the young man calling for positive media portrayals of South Central residents would not be granted the same authority as Deutch's speech in media accounts of the meeting. And yet, the young man engaged Deutch in argument. The disparities of the discursive forum did not rule out his participation nor did these disparities render his participation ineffective.

In these ways, alternative argument functions are especially important to less powerful advocates in their interactions with more powerful figures. Specialist Wilson could not have expected Secretary Rumsfeld to treat him as an equal, yet responsibility attribution indicated a significance to Wilson's participation even as Rumsfeld tried to discount his critique. Plainly put, alternative functions of argument take account of the fact that argument occurs in unequal situations. These functions suggest purposes that argument may serve in such situations. By contrast, external justification tends to presume conditions of equality. Participants are supposed to bracket social considerations and attend to the force of the better argument. All participate in decision making as equals, with each participant granted the same opportunity to direct the course of the debate. This situates argument as an all-ornothing practice, as Miller intimates in his claim that argument is "dead": either argument convinces people with different opinions, or it serves no useful function. While more powerful social actors may be content with this assessment of the status of argument, less powerful actors cannot afford to wait for others to heed their arguments. Indeed, alternative functions of argument may help establish the conditions under which more equitable justification may occur.

\section{Notes}

'I am grateful to Jean Goodwin for suggesting this distinction. Goodwin proposed the terms "weak justification" and "strong justification." I have substituted internal and external, respectively, 
to distinguish between the inferential quality of argument (internal justification) and argument as a social practice (external justification).

${ }^{2}$ Surveying the history of the Speech discipline, Herman Cohen observes that "the dominant influence of John Dewey, and particularly of his How We Think of 1910, became evident very early and continued throughout the 20s, 30s, and 40s" (1994: 320). William Keith notes that Dewey's "logic," explicated in How We Think, "was a logic of deliberative situations that dovetailed perfectly with the argumentative traditions of debate instruction" (2003: 208).

${ }^{3}$ On recent work in visual argument, see Catherine Helen Palczewski (2002: 1-23).

${ }^{4}$ For an overview of this theoretical development and others, see Robert Asen and Daniel C. Brouwer (2001a).

'For an example of how anti-fur activists have sought to redefine "private" purchasing decisions as public acts, see Kathryn M. Olson and G. Thomas Goodnight (1994: 249-276).

${ }^{6}$ See, e.g., Charles Taylor (1995).

${ }^{7}$ In his more recent work, Habermas has incorporated many of the revisions and extensions of his critics and commentators. He has explicitly affirmed multiplicity as well as fluid lines of public and private. See, Jürgen Habermas (1996: 312-14, 360-61).

${ }^{8}$ See, e.g., Mary P. Ryan (1990); Susan Zaeske (2003).

${ }^{9}$ Habermas has conceded this point with respect to women but not to laborers. Jürgen Habermas (1992: 428). On the exclusion of laborers, see Oskar Negt and Alexander Kluge (1993).

${ }^{11}$ For an instance of rejection, see Cindy L. Griffin (1996: 21-39). For efforts at reformulation, see Seyla Benhabib (1996: 67-94); Gerard A. Hauser (1999); Chantal Mouffe (2000).

"For a cogent explication of this view, see Linda Alcoff (1991-92: 5-32).

${ }^{12}$ Rawls, of course, is the main proponent of public reason. See John Rawls, Political Liberalism (1996). In the introduction to this paperback edition, Rawls presents a more flexible relationship between reasonable comprehensive doctrines and public reason, allowing the inclusion of such doctrines "provided that in due course public reasons, given by a reasonable political conception, are presented sufficient to support whatever the comprehensive doctrines are introduced to support" (ibid: liii). However, the idea of underlying normative commonality remains in his metaphoric description of a political conception of justice as a "module," which goes without amendment in the introduction to the paperback edition. As a "module," a political conception of justice is "an essential constituent part, that fits into and can be supported by various reasonable comprehensive doctrines that endure in the society regulated by it" (ibid., 12).

${ }^{13}$ See James Bohman (1996: 83-84).

${ }^{14}$ For a trenchant analysis, see John Butler (1995: 70).

${ }^{15}$ Habermas pursues this approach in his two-track model of discourse democracy. In Between Facts and Norms, he distinguishes contexts of justification from contexts of discovery. Contexts of justification arise in legislative and other institutionally sanctioned settings. In these contexts, participants justify the inclusion of specific problems on an agenda and decide among competing proposals for solving these problems. Contexts of discovery arise in the unregulated opinion formation of the public sphere. In these settings, citizens discover new issues and problems warranting legislative attention. (See Habermas 1996: 307-08.)

${ }^{16}$ U.S. Department of Defense, Office of the Assistant Secretary of Defense (Public Affairs) (2004).

${ }^{17}$ Washington Post columnist E. J. Dionne offered a typical response: "When defense secretaries and presidents give pep talks to our men and women in uniform, the troops often serve as extras whose heroism is supposed to rub off on the politicians. But at their town hall meeting with Rumsfeld on Wednesday, these men and women, many of them National Guard and reserve troops, threw away the script. These heroes did more than any politician or journalist could to challenge the administration's smug presumption that its optimistic predictions were a sufficient 
basis for planning the war in Iraq. They forced the entire nation to confront deep flaws in the administration's approach" (2004: A37). Some of the impact of Wilson's argument was deflected in subsequent media coverage as some observers wondered if a reporter had planted the question. ${ }^{18}$ See, e.g., Karlyn Kohrs Campbell (1998: 1-19); Catherine Helen Palczewski (2001: 161-186); Kent Ono and John Sloop (1995: 19-42).

${ }^{19}$ See Robert Asen (2000: 424-446); Daniel C. Brouwer (2005: 195-208).

${ }^{20}$ Quoted in Robert Asen (2001b: 149-150).

${ }^{21}$ In taking this tack, I am following those who have considered the social significance of speech acts. For an influential example, see Judith Butler (1990).

\section{References}

Alcoff, Linda. (1991-92). "The Problem of Speaking for Others," Cultural Critique 20.

Asen, Robert. (2000). "Seeking the 'Counter' in Counterpublics," Communication Theory 10.

Asen, Robert and Daniel C. Brouwer (Eds.). (2001a). Counterpublics and the State. Albany: State University of New York Press.

Asen, Robert. (2001b). "Representing the State in South Central Los Angeles." In Robert Asen and Daniel C. Brouwer (2001a).

Baird, A. Craig. (1950). Argumentation, Discussion, and Debate. New York: McGrawHill.

Beardsley, Monroe C. (1950). Thinking Straight: A Guide for Readers and Writers. New York: Prentice-Hall.

Benhabib, Seyla. (1996). "Toward a Deliberative Model of Democratic Legitimacy." In Seyla Benhabib (Ed.), Democracy and Difference: Contesting the Boundaries of the Political. Princeton, NJ: Princeton University Press.

Bohman, James. (1996). Public Deliberation: Pluralism, Complexity, and Democracy. Cambridge: Massachusetts Institute of Technology Press.

Brouwer, Daniel C. (2005). "Communication as Counterpublic." In Gregory J. Shepherd, Jeffrey St. John, and Ted Striphas (Eds.), Communication as . . . Perspectives on Theory. Thousand Oaks, CA: Sage Publications.

Bohman, James. (2003). "Deliberative Toleration," Political Theory 31.

Butler, John. (1995). "Carol Moseley-Braun's Day to Talk about Race: A Study of Forum in the United States Senate," Argumentation and Advocacy 32.

Butler, Judith. (1990). Gender Trouble: Feminism and the Subversion of Identity. New York: Routledge.

Campbell, Karlyn Kohrs. (1998). "The Discursive Performance of Femininity: Hating Hilary," Rhetoric \& Public Affairs 1.

Cohen, Joshua. (1997). "Deliberation and Democratic Legitimacy." In James Bohman and William Rehg (Eds.), Deliberative Democracy: Essays on Reason and Politics. Cambridge: Massachusetts Institute of Technology Press.

Cohen, Herman. (1994). The History of Speech Communication: The Emergence of a Discipline. Annandale, VA: Speech Communication Association. 
Dewey, John. (1910). How We Think. Mineola, NY: Dover.

Dionne, E. J. , Jr. (2004). "Truth from the Troops," Washington Post, 10 December.

Eemeren, Frans H. van, Rob Grootendorst, Francisca Snoeck Henkemans, J. Anthony Blair, Ralph H. Johnson, Erik C. W. Krabbe, Christian Plantin, Douglas N. Walton, Charles A. Willard, John Woods, David Zarefsky (1996). Fundamentals of Argumentation Theory: A Handbook of Historical Backgrounds and Contemporary Developments Mahwah, NJ: Lawrence Erlbaum Associates.

Fraser, Nancy . (1992). "Rethinking the Public Sphere: A Contribution to the Critique of Actually Existing Democracy." In Craig Calhoun (Ed.), Habermas and the Public Sphere. Cambridge: Massachusetts Institute of Technology Press.

Govier, Trudy. (1996). A Practical Study of Argument, 4th ed. Belmont, CA: Wadsworth. Griffin, Cindy L. (1996). "The Essentialist Roots of the Public Sphere: A Feminist Critique," Western Journal of Communication 60.

Habermas, Jürgen. (1989). The Structural Transformation of the Public Sphere: An Inquiry into a Category of Bourgeois Society, trans. Thomas Burger. Cambridge: Massachusetts Institute of Technology Press.

Habermas, Jürgen. (1992). "Further Reflections on the Public Sphere." In Craig Calhoun (Ed.), Habermas and the Public Sphere. Cambridge: Massachusetts Institute of Technology Press.

Habermas, Jürgen. (1996). Between Facts and Norms: Contributions to a Discourse Theory of Law and Democracy, trans. William Rehg. Cambridge: Massachusetts Institute of Technology Press.

Hauser, Gerard A. (1999). Vernacular Voices: The Rhetoric of Publics and Public Spheres. Columbia: University of South Carolina Press.

Keith, William. (2003). "Dewey, Discussion, and Democracy in Speech Pedagogy." In Gerard A. Hauser and Amy Grim (Eds.), Rhetorical Democracy: Discursive Practices of Civic Engagement. Mahwah, NJ: Lawrence Erlbaum.

Miller, Matt. (2005). "Is Persuasion Dead?" New York Times, 4 June.

Mouffe, Chantal. (2000). The Democratic Paradox. London: Verso.

Negt, Oskar and Alexander Klug. (1993). Public Sphere and Experience: Toward an Analysis of the Bourgeois and Proletarian Public Sphere, trans. Peter Labanyi, Jamie Owen Daniel, and Assenka Oksiloff. Minneapolis: University of Minnesota Press.

Olson, Kathryn M. and G. Thomas Goodnight. (1994). "Entanglements of Consumption, Cruelty, Privacy, and Fashion: The Social Controversy over Fur," Quarterly Journal of Speech 80.

Ono, Kent and John Sloop. (1995). "The Critique of Vernacular Discourse," Communication Monographs 62.

Palczewski, Catherine Helen. (2001). "Cyber-movements, New Social Movements, and Counterpublics." In Robert Asen and Daniel C. Brouwer (Eds.), Counterpublics and the State. Albany: State University of New York Press. 
Palczewski, Catherine Helen. (2002). "Argument in an Off Key: Playing with the Productive Limits of Argument." In G Thomas Goodnight (ed.), Arguing Communication and Culture. Washington, D.C.: National Communication Association.

Rawls, John . (1996). Political Liberalism, paperback ed. New York: Columbia University Press.

Reagan, Ronald. (1982). Public Papers of the Presidents of the United States: Ronald Reagan, 1981. Washington, DC: Government Printing Office.

Ryan, Mary P. (1990). Women in Public: Between Banners and Ballots. Baltimore: Johns Hopkins University Press.

Taylor, Charles. (1995). Philosophical Arguments. Cambridge: Harvard University Press. Toulmin, Stephen. (1958). The Uses of Argument. New York: Cambridge University Press. United States Department of Defense, Office of the Assistant Secretary of Defense (Public Affairs). (2004). "Secretary Rumsfeld Town Hall Meeting in Kuwait," U.S. Department of Defense Official Website, 8 December. http://www.defenselink.mil/ transcripts/2004/tr20041208-secdef1761.html (accessed June 15, 2005).

Wichelns, Herbert A. (1925). "Analysis and Synthesis in Argumentation," Quarterly Journal of Speech Education 11.

Young, Iris Marion. (1997). "Difference as a Resource for Democratic Communication." In James Bohman and William Rehg (Eds.), Deliberative Democracy: Essays on Reason and Politics, ed.. Cambridge: Massachusetts Institute of Technology Press.

Zaeske, Susan. (2003). Signatures of Citizenship: Petitioning, Antislavery, \& Women's Political Identity. Chapel Hill: University of North Carolina Press.

Robert Asen

Department of Communication Arts University of Wisconsin - Madison

6117 Vilas Hall

821 University Avenue Madison, WI 53706 rbasen@wisc.edu 